\title{
Reflections of Students and Staff in a Project-Led Partnership: Contextualised Experiences of Students-as-Partners
}

Seb Dianati, School of Languages and Cultures, University of Queensland, Australia

Yvonne Oberhollenzer, Faculty of Humanities and Social Science, University of Queensland, Australia

Contact: s.dianati@uq.edu.au

\section{ABSTRACT}

For many years, the methods of teaching and learning have remained relatively unchanged, with teachers bestowing knowledge to their students in a one-way hierarchical approach to learning. However, Student as Partners (SaP) as a concept and an ideology aims to disrupt traditional power structures of learning to offer a shared space where students become co-creators of change. This research reflects on one particular SaP project, a small-scale, project-based, institutionally resourced partnership whereby 14 students collaborated alongside 3 staff members to enhance the quality of the student experience at an Australian university. The current study aims to explore what factors mediate newly formed student-staff partnerships. Using a qualitative thematic approach, the paper draws from various online surveys to share particular contextualised experiences of student-staff partnerships. These include: learning together and navigating power dynamics, opportunities to build relationships, and balancing work and study. They became the specific strategies that mediated effective partnership. The implications of these themes highlighted that the context-dependent nature of SaP should be realised in an effort to develop institutionally appropriate practices.

\section{KEYWORDS}

student as partners, student experiences, contextualised partnership, non-academic partnerships, staff experiences

At a time of increasing university pressures to meet the needs of students, SaP provides space to realise new, authentic, and respectful relationships between students and staff. SaP offers a counter-narrative to teaching and learning in higher education by disrupting power structures and engaging students in meaningful relationships. It aims to interrupt the bystander model of traditional education by offering a place where students become active and engaged leaders through project-led environments to enhance the student experience. Cook-Sather, Bovill, and Felten (2014) define SaP as a "collaborative, 
reciprocal process through which all participants have the opportunity to contribute equally, although not necessarily in the same ways" (p. 6).

This research does not aim to offer in-depth accounts of various definitions of partnership. For a deeper account of the emergence of the term "student partner," its various definitions, and differences between "student partners" and "student voice," see Cook-Sather, Matthews, Ntem, and Leathwick (2018) and Fielding (2001, 2004, 2011). Rather, this paper follows the guidance of Cliffe et al. (2017), who offer meaning in partnership by identifying it with particular principles, such as inclusivity, trust, authenticity, empowerment, and responsibility. Additionally, the staff and students within this project set their own co-created, contextually dependent guiding principles. Despite the institution driving the vision, timeline, funding and scope of the project, the partnership model still enabled meaningful forms of student engagement to exist.

This paper follows Williamson's (2013) conceptualisation of partnership as something that "goes far beyond the mere consultation, involvement, or representation of students in decision-making. Where partnership exists, students not only identify areas for enhancement, but they help to identify ways to carry out that enhancement" (p. 8).

The current study discusses the findings of a 6-month, small-scale, university-led and -funded, first-time, project-based partnership. Students were purposively selected and exhibited positive attitudes and motivations to work alongside staff and other students to further enhance the quality of the student experience.

The guiding question of this paper aimed to examine what contextual factors mediated newly formed student-staff partnerships. The paper draws from Healey, Flint, and Harrington's (2016) standpoint to outline how context has been relatively overlooked in the literature compared to generalised frameworks. In addition, it offers a deeper understanding of staff experiences in non-academic projects, which has also been underdocumented in the field (Mercer-Mapstone et al., 2017). The research was designed with students at its heart, as students co-created the research questions for the surveys. The findings from the paper outline three themes that were consistent across the analysis of the survey reflections completed by both students and staff. These themes were (a) learning together and navigating power dynamics, (b) opportunities to build relationships, and (c) balancing work and study.

\section{CONTEXTUAL EXPERIENCES IN SAP}

SaP in its simplest sense is underpinned by co-creation. It promotes a new concept of relationship where students and staff create, evaluate and analyse purposes together (Bovill, Cook-Sather, \& Felten, 2011). Drawing upon Cook-Sather's (2018) work, this paper initially reviews her literature in the field of Student as Learners and Teachers (SaLT) in the United States. Although it has a different name, it shares many of the broader philosophies of SaP. According to Cook-Sather et al. (2014a), development of new customs of academic freedom between staff and students is made possible through meaningful and respectful relationships. However, Cook-Sather (2010) also reflect that some staff might perceive SaP as fanciful and that power relations may be too ingrained to be disrupted.

Acknowledging and interrupting authority can be difficult as it is both invisible and engrained through formal schooling. However, students are more conscious of power dynamics as they are often marginalised. Cook-Sather et al. (2014c) also noted that most publications do not address staff experiences and tend to focus on student outcomes. This is evident in the higher proportion of publications on student outcomes rather than staff 
outcomes (Mercer-Mapstone et al., 2017). This paper addresses this gap by triangulating reflections from staff and students to highlight consistent mediating themes.

However, not all partnerships aim to have a clear, deliverable outcome (Bryson, 2016). For this reason, SaP can be seen as both a process and a product (Healey, Flint, \& Harrington, 2014). While frameworks may help scale up a project within a university, its adoption across the spectrum of possible SaP applications should be tempered with caution. For instance, a framework for improving teaching and learning at the course level (see, e.g., Jensen \& Bennett, 2016) would not fit extracurricular governance-based projects like those presented in Barrineau, Schnaas, Engström, and Härlin (2015). Coupled with the low rates of inter-institutional and cross-institutional partnerships (Mercer-Mapstone et al., 2017), a one-size-fits-all framework may not be appropriate in all contexts.

There also has been an overreliance of SaP used solely for teaching and learning purposes (Mercer-Mapstone et al., 2017). Hence, project-based initiatives, outlined in this study, need greater contributions to the debates regarding student partnerships in the field to reflect from a non-academic, teaching and learning perspective of SaP. Due to the relative infancy of the field, student partnerships with PhD students and professional staff are limited, which restricts the breadth of their contextual understandings. Moreover, results in the literature have been overwhelmingly positive in favour of partnership, with little critique of the consequential or unexpected outcomes of partnership that arise from the contextual and subjective interests in which they were created.

It is important to distinguish between student-voice (Cook-Sather, 2014b) and student-action (Dunne \& Zandstra, 2011). Student-voice aims to understand students' perspectives while student-action is where students often take the lead role in the partnership. In light of this distinction, the project team adopted a new faculty-wide, institutionally funded, student-voice partnership in an effort to enhance the quality of the student experience.

\section{CO-CREATING THE GUIDING PRINCIPLES OF AN ALTERNATIVE CONCEPTUAL MODEL}

Moving away from a general template, the partnership set out to co-create three guiding principles agreed upon by all parties. The first co-created principle, titled "diverse contributions," aimed to ensure that there was a diversity of experiences and ideas of the student partners to promote greater equity and inclusion in the project. The project sought to address this concern by deliberately recruiting students from a diverse range of academic as well as cultural and linguistic backgrounds. For this reason, strong academic achievement was not a criterion for recruitment.

The second co-created principle was "shared responsibility." The literature also identifies this as critical to SaP (Marquis et al., 2016), and ongoing clarification of goals was critical to building a sense of shared responsibility between partners. Dwyer (2018) also observed that accountability mechanisms promoted a more equal conception of partnership. The team met weekly to discuss and seek feedback on critical aspects of the project, which also promoted accountability and transparency of roles. An online collaboration tool was used to update students between meetings and provide a space to share documents. This reinforced the team's shared responsibility for delivering project outcomes and helped students and staff feel connected to project activities.

Lastly, "structured reflection" encouraged students and staff to think, engage, and meaningfully connect their current experiences. Students and staff volunteered to complete three online reflections before, during, and after the partnership about their experience of 
working together. The research methods, techniques and questions used in these reflections are outlined in Table 1 . The project context is similar to Marquis, Jayaratnam, Mishra, and Rybkina's (2018) partnership, which was exclusive to particular students who had already presented motivations for participating in partnership.

Before discussing the implications of this research, the paper heeds Healey and Healey's (2018) advice that newly formed partnerships must be understood by the context in which they operate. Gibbs (2010) also stresses the importance of context, as otherwise it may lead to inappropriate best practice models. This paper contributes more broadly to the international SaP literature by celebrating the uncertainty of partnerships through the appreciation of the subjective, lived experiences within them and by questioning generic frameworks that camouflage the context in which they operate (Cliffe et al., 2017). As Healey and Healey (2018) state, "people who have experienced partnerships are arguably in a better position to reflect on partnership through these conceptual frameworks than those who are new to this approach" (p. 6). This research aims to contribute and extend Healey's and Healey's (2018) contextual implications of partnership by proposing that newly formed partnerships could benefit from setting their own set of co-created guiding principles relevant to their motivations, attitudes, needs, and context.

\section{RESEARCH METHOD}

The next section identifies the research question and method to make explicit the scope and objectives of the research.

Our research question asks: What contextual factors mediate newly formed

\section{student-staff partnerships?}

The partnership project aimed to investigate the undergraduate student experience in the Faculty of Humanities and Social Sciences with a specific focus on retention and employability. An expression of interest was provided to staff members in the student experience team, and three staff members showed interest in being involved in the project. Three professional staff worked with 14 students from June to December in 2016 and conducted three main undertakings together. They:

1. Developed guiding principles through focus groups to unpack the relationship and develop good practice principles between students and staff.

2. Piloted and evaluated discipline-based employability workshops that included "idea-to-enterprise" approaches as well as traditional career experiences.

3. Devised a workflow model for creating mutually beneficial and supportive student-staff partnerships in the future.

\section{Participants}

Fourteen students and three professional staff participated. The fourteen students were recruited over a 2-month period and represented a diverse demographic of the student body. The average age was 22 years old, with a range between 19-28 years of age. Most students were in their third year $(n=6)$ and fifth year $(n=4)$, with two in their second year and one student in their fourth year of study. The majority of students were domestic students (Permanent Resident or Australian Citizen $n=13$ ), with one international student recruited for the project. The participants were mostly female $(n=9)$; however, a sizable minority of male students $(n=5)$ participated in the project. The majority of students were 
studying full-time ( $n=13)$, with one student studying part-time. The participants of the study studied across a broad range of disciplines within the humanities, social sciences, and education to ensure a representative spread of students within the faculty. Academic achievement was not considered as a selection criterion for recruitment, thus giving students with mixed academic performances the opportunity to participate in the program. Student motivations for involvement was considered during the selection process when candidates were shortlisted and interviewed.

\section{Research design}

Merriam (2009) outlines an interpretative paradigm of lived experience, wherein each individual's social reality is self-constructed and subjective experience is valued by researchers. Given the nature of this project (i.e., highly context-dependent and grounded in social interaction), a qualitative data-collection approach was undertaken. The current study adopted Patton's (2005) broad inductive thematic analytical approach to design where the research was driven by practice and themes organised according to the reflections provided during the research process. This was conducted in five steps. The first was through the familiarisation of data. The second was assigning codes to the data. The third stage aimed to determine any patterns or themes in the identified codes. The fourth step included a method of triangulation to ensure that the theme was expressed by both students and staff. The last step was to review and name each theme that best encapsulated the grouped codes (Merriam, 2009). For instance, time and work commitments were themed into a broader category of "balancing work and study."

An anonymous survey was chosen to ensure that staff and students could openly express their concerns without coercion. Furthermore, the anonymity reduced opportunities to ascertain the identity of the respondents which may have otherwise been possible due to the small sample size. The questions for each of the research methods are listed in Table 1. The research questions were co-created with students. The same questions were given to staff and students to ensure consistency of the data. The data was transcribed and themes that appeared continually were then identified for further scrutiny. For example, using a method of thematic triangulation, if staff and students both referred to "workload" in the transcription, it was identified as a theme for further interrogation.

\section{Research method}

The data was analysed using two different research methods: reflective journals and a focus group. The first, the reflective journals (i.e., Reflection Journal 1, 2, and 3, as presented in Table 1), used an open-ended online survey to gain feedback about their experiences in the project. Students and staff who were part of the project team were asked to complete three anonymous online written reflections before, during, and at the end of the project. The aim of the reflections was to document student and staff experiences with engaging in partnership and to identify common mediating themes consistent among both staff and students. Although staff drafted the reflective questions, students had the opportunity to change and add questions through group discussions. The final questions reflected the ideas and interests of both students and staff.

The second method were focus groups (i.e., Journal Reflection 4). Here, students were asked to attend a focus group at the end of the project to discuss their reflections and insights gained at the end of the project. One focus group was led by a staff member and the other was led by a student. Upon receiving signed consent, students were recorded and 
their data was transcribed. The information was then grouped into common themes which were identified by both staff and students.

During the project, student partners requested an additional opportunity to discuss and reflect on their partnership experience. In response, staff organised an informal conversation to better understand how students' partnership experiences were meaningful to them. This dialogic process enhanced the credibility and trustworthiness of the written reflections because it helped highlight what was meaningful to participants during the partnership process.

Table 1: Description of data-collection questions and method

\begin{tabular}{|c|c|c|}
\hline $\begin{array}{l}\text { RESEARCH } \\
\text { TECHNIQUE }\end{array}$ & $\begin{array}{c}\text { DESCRIPTION OF } \\
\text { DATA COLLECTION } \\
\text { METHOD }\end{array}$ & REFLECTIVE QUESTIONS \\
\hline $\begin{array}{l}\text { Reflection } \\
\text { Journal } \\
1\end{array}$ & $\begin{array}{l}\text { Thirteen students } \\
\text { and three staff } \\
\text { completed an } \\
\text { anonymous online } \\
\text { survey. }\end{array}$ & $\begin{array}{l}\text { What is your definition of a partnership between students } \\
\text { and staff? } \\
\text { What would you like to learn/achieve while working on this } \\
\text { project? }\end{array}$ \\
\hline $\begin{array}{l}\text { Reflection } \\
\text { Journal } 2\end{array}$ & $\begin{array}{l}\text { Ten students and } \\
\text { three staff } \\
\text { completed an } \\
\text { anonymous online } \\
\text { survey. }\end{array}$ & $\begin{array}{l}\text { In what ways have your ideas about student-staff } \\
\text { partnership changed throughout this project? } \\
\text {. How do you feel decisions about responsibilities between } \\
\text { students and staff have been made on this project so far? In } \\
\text { what ways would you like to see them changed? } \\
\text {. What have you learnt while working on the project, and how } \\
\text { might you apply these skills in the future? } \\
\text { Thinking about your time on the project, what would you } \\
\text { have done differently to enhance your partnership } \\
\text { experience? }\end{array}$ \\
\hline $\begin{array}{l}\text { Reflection } \\
\text { Journal } 3\end{array}$ & $\begin{array}{l}\text { Nine students and } \\
\text { three staff } \\
\text { completed an } \\
\text { anonymous online } \\
\text { survey. }\end{array}$ & $\begin{array}{l}\text { What was your top challenge and your top success while } \\
\text { working on this project? What did you learn from these } \\
\text { experiences? } \\
\text { What were the outcomes of the project? In what ways did } \\
\text { we achieve (or not achieve) those outcomes? } \\
\text { If you could do this project again, what would you do } \\
\text { differently and what would you keep the same? } \\
\text { What suggestions do you have for enhancing student-staff } \\
\text { partnership in future projects? }\end{array}$ \\
\hline $\begin{array}{l}\text { Reflection } 4 \\
\text { (Focus } \\
\text { Group) }\end{array}$ & $\begin{array}{l}\text { Eleven students } \\
\text { were divided into } \\
\text { two groups for a } \\
\text { semi-structured } \\
\text { reflective } \\
\text { discussion, both of } \\
\text { which were } \\
\text { facilitated by staff. } \\
\text { The session was } \\
\text { recorded and } \\
\text { transcribed. } \\
\text { Transcripts were } \\
\text { de-identified. }\end{array}$ & $\begin{array}{l}\text { Thinking about our shared expectations that we developed } \\
\text { at the beginning of the project, do you think we met these } \\
\text { expectations together? Is there anything that we missed or } \\
\text { could have improved? } \\
\text { - What was your most memorable experience working on the } \\
\text { project? } \\
\text { What suggestions do you have for enhancing student-staff } \\
\text { partnership in future projects? }\end{array}$ \\
\hline
\end{tabular}




\section{FINDINGS}

Based on the reflections of team members, the partnership model used for this project appeared to foster a positive and mutually beneficial experience for both students and staff. Throughout the project, students and staff were asked to reflect on their experience and how they could improve their current partnerships. As such, this section explores findings related to the experiences of working in partnership for students and staff and additionally outlines strategies to foster effective staff-student relationships in future. The findings were guided by the study's aim to discover the factors that mediate or enhance effective partnership. Three themes were identified: learning together and navigating power dynamics, opportunities to build relationships, and balancing work and study.

\section{Learning together and navigating power dynamics}

While working in partnership, both students and staff learnt new skills that enhanced their employability and service to the community. These skills were contextually dependent to this newly formed partnership. Students and staff also differed in their conceptions of power dynamics at the beginning of the project, which these excerpts demonstrate:

I would like to learn how to communicate with others while in partnership. I find it difficult to navigate power relations in the workplace. While I would love to contribute to work, I am very aware of my place in the hierarchy and how I approach decisionmaking differs according to my own position of power/lack of. (Student, Journal Reflection 1)

A partnership to me entails mutual respect, equality and collaboration in decision making. I understand that there exists a power dynamic, however I am keen to genuinely engage students in an equal and meaningful way. (Staff, Journal Reflection 1)

In particular, the students' reflections tended to indicate an element of discomfort with the existing imbalanced power dynamic. However, Glasser and Powers (2011) represent discomfort as a productive component of partnership which should be embraced accordingly. Students expressed a helper-helped relationship at times which may need reconfiguration to further foster a relationship that mediates power relations. Equally important was the need to provide space for opportunities to build intellectual, emotional, and social relationships together. At the beginning of the project, students identified skills that they wanted to develop and connected skill development to their own employability. As they progressed through the project, they felt that they learned technical skills that would make them more employable (e.g., data analysis, event management, and focus group facilitation) while improving their confidence, interpersonal communication, and analysis skills. One student noted,

In my eyes, I see the result, the end goal, the product ... as the most important thing and definitely the part that I've liked most about the project. Because it's everybody working mutually together, cooperatively.... We are all cognisant of the steps that it takes to get to where we want to be at the end of the project. (Student, Reflection 4) 
Other skills included presenting to key stakeholders, organising events, learning more about working in a team, and contributing to a "real research project."

Learning did not come without challenges. Students found that they underestimated the time it would take to learn and apply a new skill. For example, some students underestimated the time it would take to learn a new software, which in turn affected how quickly they could complete the task. Similarly, an event-planning student partner had never organised catering before and felt uncomfortable voicing their lack of knowledge to do so. As a result, they did not seek help and found the task difficult. By the end of the project, the staff felt like they had learned from the student partners and expressed that they enjoyed building a relationship with learners more than anticipated.

\section{Opportunities to build relationships}

Students and staff considered a range of strategies for working with other people, including within the project team and with external stakeholders. Three factors were important here: communicating regularly, fostering peer interaction, and engaging external stakeholders.

\section{Communicating regularly}

To manage regular communication, students expressed that certain different modes (i.e., emails, calling, texting, face-to-face meetings, and cloud-based platforms) suited their student lifestyle and helped them to stay engaged with the project. Many students found that face-to-face interactions were the most effective way to maintain relationships. Weekly meetings were viewed as important to maintaining a connection with the team and the project outcomes. Similarly, some students enjoyed working in the office alongside staff members and explained that it was easier to ask for clarification. One student noted,

I enjoyed coming into the office. ... I think that was really good to be able to come in and see everyone. You can just ask really quick questions.... Rather than writing an email and taking the time you just say, what does this mean? (Reflection 4)

\section{Fostering peer interaction}

Fostering peer interaction was outlined as an important aspect of building relationships. Staff sought to foster peer-to-peer connections, particularly for organising events. Staff found that "having peers to talk to peers resulted in much richer information and ideas for action, as students really opened up to other students" (Staff, Journal Reflection 2). Each student was paired with another student to co-organise the event, a decision that was based on informal feedback from the students responsible for events. This provided a positive support framework for students and shifted their focus from seeking solutions from staff to solving challenges together. Further, staff found it difficult to let students fail and stepped in quickly to ensure that activities stayed on track. One staff member noted,

Sometimes, it was difficult to know when to step in and complete a task or let the student complete it themselves. This was a common issue when the events drew nearer. I think I could have stepped away a bit more and let the students figure out that they had to complete certain tasks in order for the event to happen. (Staff, Journal Reflection 3) 


\section{Engaging external stakeholders}

A challenge raised by students and staff alike concerned engaging external stakeholders, including promoting events and focus groups to students, working with student societies, and engaging with relevant staff. Stakeholder engagement was a critical part of the project, and some students felt that this requirement was beyond their skillset. Students suggested that the student partner job description should explicitly outline that the role entails promoting and advertising opportunities to other fellow students.

Additionally, students suggested that the student partner induction should include training that focuses on the complexities of promoting opportunities to students and other stakeholders.

With respect to engaging with staff, students suggested that it would be beneficial to provide student partners with earlier and more frequent opportunities to engage with school staff. In this project, staff took responsibility for this outreach, but did not communicate this clearly to students. Some students felt as though they did not work as efficiently in areas of the project because they were not sufficiently connected to staff. Lastly, with respect to student societies, it was considered important to provide training to new student society executives on how to manage events in the university context and to complement the current work of student societies (e.g., social networking evenings) with employability and skill-building seminars.

\section{Balancing work and study}

Students' greatest concern was the ability to balance work and study. One clear outcome of the project was a need to offer a range of strategies for students to balance each. By providing flexibility, communicating assessment schedules, and reviewing the recruitment timeline, some avoidable stresses for students could have been alleviated.

\section{Flexibility}

The students enjoyed the flexibility of the work hours provided, as they could fit the project work into their schedules. Staff negotiated deadlines with students and allowed them flexibility to undertake the task at their discretion. Maintaining flexibility was therefore a critical component of ensuring work-study balance, as it allowed students to accommodate multiple priorities.

\section{Communicating assessment schedules}

With respect to the assessment schedule, students suggested providing a more concrete assessment timetable for the semester to be used by staff when assigning tasks. Even though students provided a rough overview of their semester to staff at the beginning of the project, some felt that staff did not adequately consider their schedules. One student suggested creating a live document where they could submit their weekly timetables, as student commitments often change week to week.

\section{Recruitment timing}

Lastly, in relation to recruitment timing, students agreed that recruitment for the position could have happened earlier in the semester to allow for training and extra preparation for the focus groups and events. Students believed the short time frame between recruitment, induction, and implementing their tasks was challenging. Students also agreed that there was no assessment in the first few weeks of the semester and that 
they could have used this time to focus on their role. This challenge caused considerable stress for students, particularly in the middle of the project, when students attempted to meet project and assessment deadlines simultaneously. This manifested itself in different ways for different students. One student felt that they were not given enough choice about event timing, which coincided with assessment. Another found it easy to concentrate on work and took on a number of additional tasks that caused stress when assignments were due. Others felt overwhelmed and wished they had communicated more openly about these challenges. Although their perspectives varied, the challenge remained the same throughout the project:

I wish that I had let the Staff Partners know when I was struggling with my workload. (Student, Reflection 2)

My top challenge was time. Having to juggle the Student Partner role with my other commitments and studies was at times very stressful despite the fact that I keep a calendar and a planner at my desk.... It was quite challenging at some points to meet my Student Partner deadlines within the required timeframes and perhaps I should have negotiated these further or found strategies to work more efficiently to meet them. (Student, Journal Reflection 3)

If I were to change anything, I would change my state of mind. Although (mostly) not related to how the project went, I feel that if I were to be calmer and approach my event planning with less worry about how it would affect my own work and image as a student, I could've given more to the project. (Student, Journal Reflection 3)

As far as my [work] ... just everything kind of happening towards the end of semester, everything kind of needed to be prepared right in the middle of my exams. ... I found it very hard to manage but I did." (Student, Journal Reflection 4)

\section{Other mediating factors}

Two sub-themes that arose during analysis that were identified by both staff and students but were not prevalent enough to be categorised as an overarching theme were (a) the need for student renumeration and (b) the need for a shared office.

Both students and staff suggested that paying students was a valuable and undisputedly mediating factor for effective partnership. Both staff and students stressed the importance of financial incentives in ensuring the quality of outcomes and for fostering a sense of equality within the partnership. Payment helped students to prioritise throughout the semester, resulting in better quality work. Renumeration was also seen as legitimising the partnership and encouraged students to take the partnership more seriously. This was supported by both staff and students:

Don't underestimate the value of paying students for their work. Students expressed their feelings of equality, of partnership, and genuine contribution, all stemming from the initial fact of being paid as a co-worker on the project. (Staff, Journal Reflection 3) 
It was a good reinforcement of the Student Partner message that we are actually being treated as though we have serious skills that we can offer. I think it would have been confusing if the project description had have been it's all about equal partnership and equal work and then it was $\$ 10$ an hour. (Student, Reflection 4)

The second key factor worth mentioning was the lack of access to an office or a shared space. Students thought that the office set-up, which was behind a locked door that only staff could access, created a barrier and made it harder to have informal conversations throughout the day. This developed as the second key sub-theme that negatively mediated SaP in this context.

\section{DISCUSSION}

The paper identified three particular co-created guiding principles that may help support newly formed partnerships as considerations for future work. The set of guiding principles concerning diverse contributions, shared responsibility, and structured reflection coincided within three themes identified in this research. For instance, the theme "learning together and navigating power dynamics" and the guiding principle of shared responsibility both related to how well students and staff could set specific, measurable, clear, and accountable goals. Moreover, staff and students found that when creating opportunities to build relationships, it was critical to develop multiple channels of communication to foster teamwork, provide opportunities for students to work with each other, and deliver support to engage with other students. By encouraging a range of contributions, this theme coincided with the principle of diverse contributions. Lastly, "balancing work and study" became a consistent theme in the findings and, through the principle of structured reflection, students were given flexibility in accommodating student work schedules.

Revisiting the research question regarding what contextual factors mediate newly formed student-staff partnerships, we identified several considerations. For instance, a mediating factor identified in relation to the theme "learning together and navigating power dynamics" was the need to set a clear message about the benefits of partnership for both students and staff throughout the life of the project. This could be inclusive of, but not limited to, training and development surrounding power, attitudes, and preconceived beliefs. This could be particularly helpful for first-time, project-based, extracurricular partnerships that may similarly encounter this aspect as a mediating factor. Both students and staff anticipated navigating power dynamics as an issue and as such were uncertain about whether genuine partnership was possible. However, students were surprised by the high level of effort and engagement staff put into the project. This was similar to CookSather et al.'s (2014) findings that staff who actively engage with student perceptions and contributions, rather than merely dismissing them, found SaP transformative, both emotionally and cognitively. It is therefore prudent to note Cousin's (2010) realisation that student-staff partnership must be prepared for and embrace an emotional shift, just as much as a cognitive shift.

With respect to providing opportunities to build relationships, students focused heavily on employability skills. Comparatively, staff focused on how to provide more effective opportunities for collaboration with students. Students who were the most willing to learn and take on new challenges appeared to receive the most benefits from the partnership. All staff believed that opportunities for partnership with students would benefit the project outcomes, and consequently, that they must foster collaboration with 
students and help them learn together and navigate power dynamics. This research supports earlier findings within the field that power dynamics must be taught, or at least acknowleged, for newly formed partnerships (Glasser \& Power, 2011).

To this end, it is worth tailoring communication about the benefits of partnership to staff and students that relates to their lived experiences, attitudes, and motivations. This will support a shared learning experience while offering opportunities to build relationships with each other. For staff, the project promoted the development of a diverse range of perspectives and insights into how students learn, while leveraging students' expertise and ideas to improve teaching and learning. It also assisted staff in building capacity in collaborative work environments where a power dynamic exists. To this end, the current paper adds to the body of knowledge in non-academic staff experiences in SaP, which has been limited in the literature (Mercer-Mapstone et al., 2017).

At the end of the project, students expressed that they had gained a greater understanding of the university as an institution and felt more confident in having opportunities to influence change. Matthews, Dwyer, Hine, and Turner (2018) noticed a similar phenomenon whereby, students often moved from "co-creators" to "change agents" organically as they expressed an interest in initiating future teaching and learning activities in collaboration with staff (rather than waiting for an opportunity to become involved). This was an unanticipated outcome of the partnership model and opens up the possibility of students initiating new project ideas and seeking avenues to collaborate with staff. However, Cook-Sather (2014) suggests that such change can be "troublesome, transformative, irreversible, and integrative" (p. 186). In order to avoid alarming potential staff partners, Cook-Sather (2014b) suggests proposing SaP to staff by framing the conversation around dialogue, rather than change. Given the traditional power dynamic at university, fostering students to become change agents from co-creators would require a structured, strategic, and resourced approach to SaP.

Regarding opportunities to build relationships, another contextual factor that mediated effective partnership was space, which only became apparent during the project. Students noted that a lack of a shared space was a barrier to effective partnership and that it undermined the whole concept of equality as they were unable to readily access a swipe card to enter the office and had to rely on staff members to let them in. A more open, accessible space would have encouraged more interaction between students and staff and may have been more convenient for project-based learning.

\section{CONCLUSION}

The paper offered practical strategies for others interested in developing student partner relationships in an effort to (a) examine the importance of appreciating the contextspecific factors of partnership and (b) draw conclusions from the three themes derived from the project for the use in future projects within the institution in which it was developed. Offering moments of reflection before, during, and after as a collaborative learning activity was critical as it allowed students and staff to explicitly reflect on the relational and socioemotional aspects of partnership.

With respect to opportunities to build relationships, the need for multiple channels of communication to foster more meaningful and authentic relationships needs to be considered. Understanding and balancing work and study was identified as students' biggest challenge during the project. However, this was overcome by giving students flexibility in 
their work agendas, creating shared assessment rosters, and recruiting students earlier to allow for additional training and preparation.

The current research was successfully reviewed according to research ethics committee guidelines (Ethics approval number: 2016001181).

\section{ACKNOWLEDGEMENTS}

The research was supported by the Deputy Vice-Chancellor (Academic) at The University of Queensland. We thank the team of staff and students engaged in the 2016 Undergraduate Student Experience Project in the Faculty of Humanities and Social Sciences who contributed to the research.

\section{NOTE ON CONTRIBUTORS}

Seb Dianati is a Teaching Fellow specialsing in Digital Curriculum Design. Seb has successfully led thirteen different student partnership projects in the School of Languages and Cultures across Japanese, Chinese and Applied Linguistics in an effort to enhance teaching and learning practices and the student experience.

Yvonne Oberhollenzer is the director of the Student Futures Team in the Faculty of Humanities and Social Sciences (HASS). Yvonne dedicates her time connecting HASS students with employability experiences and runs various project and programs in an effort to increase their student experience in HASS and the wider university community.

\section{REFERENCES}

Barrineau, S., Schnaas, U., Engström, A., \& Härlin, F. (2015). Breaking ground and building bridges: A critical reflection on student-faculty partnerships in academic development. International Journal for Academic Development, 21(1), 79-83. https://doi.org/10.1080/1360144X.2015.1120735

Bovill, C., Cook-Sather, A., \& Felten, P. (2011). Students as co-creators of teaching approaches, course design, and curricula: Implications for academic developers. International Journal for Academic Development, 16(2), 133-145. https://doi.org/10.1080/1360144X.2011.568690

Bryson, C. (2016). Engagement through partnership: students as partners in learning and teaching in higher education. International Journal for Academic Development, 21(1), 84-86. https://doi.org/10.1080/1360144X.2016.1124966

Cliffe, A., Cook-Sather, A., Healey, M., Healey, R., Marquis, E., Matthews, K. E., MercerMapstone, L., Ntem, A., Puri, V., \& Woolmer, C. (2017). Launching a journal about and through students as partners. International journal for Students as Partners, 1(1). https://doi.org/10.15173/ijsap.v1i1.3194

Cook-Sather, A. (2010). Students as Learners and Teachers: taking responsibility, transforming education, and redefining accountability. Curriculum Inquiry, 40(4), 555-575. https://doi.org/10.1111/j.1467-873X.2010.00501.x

Cook-Sather, A. (2014a). Student-faculty partnership in explorations of pedagogical practice: A threshold concept in academic development. International Journal for Academic Development, 19(3), 186-198. https://doi.org/10.1080/1360144X.2013.805694 
Cook-Sather, A. (2014b). The trajectory of student voice in educational research. New Zealand Journal of Educational Studies, 49(2), 131-148. Retrieved from https://search.informit.com.au/documentSummary; dn=842480978608459;res=IELN $\underline{Z C}$

Cook-Sather, A. (2014c). Undergraduate students as partners in new faculty orientation and academic development. International Journal for Academic Development, 21(2), 151-162. https://doi.org/10.1080/1360144X.2016.1156543

Cook-Sather, A. (2018). Developing "Students as Learners and Teachers": Lessons from ten years of pedagogical partnership that strives to foster inclusive and responsive practice. The Journal of Educational Innovation, Partnership and Change, 4(1). https://doi.org/10.21100/jeipc.v4i1.746

Cook-Sather, A., Bovill, C., \& Felten, P. (2014). Engaging students as partners in learning and teaching: A guide for faculty: John Wiley \& Sons.

Cook-Sather, A., Matthews, K. E., Ntem, A., \& Leathwick, S. (2018). What we talk about when we talk about students as partners. International Journal for Students as Partners, 2(2), 1-9.

https://doi.org/10.15173/ijsap.v2i2.3790

Cousin, G. (2010). Neither teacher-centred nor student-centred: Threshold concepts and research partnerships. Journal of Learning Development in Higher Education (2). Retrieved from http://journal.aldinhe.ac.uk/index.php/ildhe/article/view/64

Dunne, E., \& Zandstra, R. (2011). Students as change agents: New ways of engaging with learning and teaching in higher education. England: EsCalate/Higher education Academy Publication. Retrieved from https://dera.ioe.ac.uk/id/eprint/14767

Dwyer, A. (2018). Toward the formation of genuine partnership spaces. International Journal for Students as Partners, 2(1), 11-15. https://doi.org/10.15173/ijsap.v2i1.3503

Fielding, M. (2001). Beyond the rhetoric of student voice: New departures or new constraints in the transformation of 21st century schooling? Paper presented at the Forum for promoting 3-19 comprehensive education. Retrieved from https://www.researchgate.net/profile/Michael Fielding/publication/245584644 Be yond the Rhetoric of Student Voice new departures or new constraints in th e transformation of 21st century schooling/links/5471bf360cf216f8cfad144a.pdf

Fielding, M. (2004). Transformative approaches to student voice: Theoretical underpinnings, recalcitrant realities. British educational research journal, 30(2), 295-311. https://doi.org/10.1080/0141192042000195236

Fielding M. (2011) Patterns of Partnership: Student voice, intergenerational learning and democratic fellowship. In: Mockler N., Sachs J. (eds) Rethinking educational practice through reflexive inquiry. Professional Learning and Development in Schools and Higher Education, vol 7. Springer, Dordrecht https://doi.org/10.1007/978-94-007$\underline{0805-1 \quad 5}$

Gibbs, G. (2010). The importance of context in understanding teaching and learning: Reflections on thirty five years of pedagogic research. Keynote presented at the International Society for the Scholarship of Teaching Annual Conference, Liverpool, UK. Retrieved from http://issotl10.indiana.edu/plenary.html

Glasser, H., \& Powers, M. (2011). Disrupting traditional student-faculty roles, 140 characters at a time. Teaching and Learning together in higher education, 1(2), 5. 
Healey, M., Flint, A., \& Harrington, K. (2014). Engagement through partnership: Students as partners in learning and teaching in higher education. York, UK: The Higher Education Academy. Retrieved from https://www.advance-he.ac.uk/knowledgehub/engagement-through-partnership-students-partners-learning-and-teachinghigher

Healey, M., Flint, A., \& Harrington, K. (2016). Students as Partners: Reflections on a conceptual model. Teaching and Learning Inquiry, 4(2). Retrieved from https://imss.org/index.php/TLI/article/view/57438

Healey, M., \& Healey, R. (2018). 'It depends': Exploring the context-dependent nature of students as partners practices and policies. International Journal for Students as Partners, 2(1), 1-10. https://doi.org/10.15173/ijsap.v2i1.3472

Jensen, K., \& Bennett, L. (2016). Enhancing teaching and learning through dialogue: A student and staff partnership model. International Journal for Academic Development, 21(1), 41-53. https://doi.org/10.1080/1360144X.2015.1113537

Marquis, E., Puri, V., Wan, S., Ahmad, A., Goff, L., Knorr, K., Vassileva, I., \& Woo, J. (2016). Navigating the threshold of student-staff partnerships: A case study from an Ontario teaching and learning institute. International Journal for Academic Development, 21(1), 4-15. https://doi.org/10.1080/1360144X.2015.1113538

Marquis, E., Jayaratnam, A., Mishra, A., \& Rybkina, K. (2018). "I feel like some students are better connected": Students' perspectives on applying for extracurricular partnership opportunities. International Journal for Students as Partners, 2(1), 6481. https://doi.org/10.15173/ijsap.v2i1.3300

Matthews, K. E., Dwyer, A., Hine, L., \& Turner, J. (2018). Conceptions of students as partners. Higher Education, 76, 957-971. https://doi.org/10.1007/s10734-018-0257y

Mercer-Mapstone, L., Dvorakova, S. L., Matthews, K., Abbot, S., Cheng, B., Felten, P., Knorr, K., Marquis, E., Shammas, R., \& Swaim, K. (2017). A systematic literature review of students as partners in higher education. International Journal for Students as Partners, 1(1). https://doi.org/10.15173/ijsap.v1i1.3119

Merriam, S. B. (2009). Qualitative research: A guide to design and implementation. San Francisco, CA: Jossey-Bass.

Patton, M. Q. (2005). Qualitative research. Encyclopedia of statistics in behavioral science. https://doi.org/10.1002/0470013192.bsa514

Williamson, M. (2013). Guidance on the development and implementation of a student partnership agreement in universities. Student Participation in Quality Scotland. Retreived from https://www.sparqs.ac.uk/upfiles/Student\%20Partnership\%20Agreement\%20Guida nce\%20-\%20final\%20version.pdf 